[事例紹介]

\title{
イメージ・スキャナを利用した オフライン・ティーチング・システム*
}

毎 川保 久** 天 野 光 明**

\section{1. は じめに}

産業用ロボットは, 教示データの変更により様々な作 業を行ならことができる点で非常にフレキシブルである. しかし，作業変更のたびに，教示作業を行なら必要があ り，またこの教示作業は，人手により行なっているのが 現状である. その為に，この教示作業を効率よく行なう ッールの必要性があり, オフライン・ティーチング・シ ステム等 $(1) ， 2) ， 3), 4)$ 等) の様々な, 研究開発が行 なわれている。これらのシステムは，教示作業だけでな く，3次元表示により，ロボットとまわりの環境（ワー クや周辺機器等）を表示した動作シミュレーション等を 行ない教示データの確認を行ならように開発されている。 しかし，このような動作シミュレーションも, 複雑で 3 次元的な作業には必要であるが，口ボットの作業として 2 次元的な作業も多く, この場合, 教示作業の簡易化が 重要なポイントとなる。そこで，まず，パソコン 2 次元 CAD を利用して, 直角座標形や水平多関節形の口ボッ ト用, オフライン・ティーチング・システムを開発した。 これにより教示作業時間の短縮を計った. しかし，この 方式は, $\mathrm{CAD}$ 操作の習得, そして, 多品種の対象物に 対する図形入力に時間がかかり, 操作性の向上が課題と なった.

そこで，CAD への図形入力作業をより簡易化する手 段として，手書き図形をイメージ・スキャナ（図形読み 取り装置) に入力することにより，ロボットの作業動作 データを生成するシステムを開発したので紹介する.

\section{2. システム構成}

今回開発したイメージ・スキャナを利用したオフライ ン・ティーチング・システムは, 図1飞示すパソコン, イメージ・スキャナ，口ボット等で構成している. 使 用したパソコンは，東芝製ラップトップ・パソコン J3100 で, 3 MB の RAM-DISK 付である. イメージ・

原稿受付 1989 年 5 月 11 日

* Off-line Teaching System Using the Image Scanner

**株式会社 東芝
スキャナは, パソコンの拡張ニニットKインタフェース 基板を介して接続している.

イメージ・スキャナの仕様は, 以下の通りである.

○読及取り方式 : CCD イメージ・センサ平面走査方式 ○入力原稿サイズ : 走查幅 $216 \mathrm{~mm}$, 走査長 $297 \mathrm{~mm}$ A 4 版サイズ（最大）

○読み取り線密度 : 180,200，240，300[ドット/イン 千]

○出力 : 白黒濃度

○インタフェース: パラレル

ロボットは，東芝製産業用ロボットで，直角座標形や 水平多関節形の口ボットとロボット・コントローラ SR-5000 の構成となっている.

ロボット・コントローラは, BASIC 言語に近い各種 ・命令を持つロボット言語 SCOL-I を持ち多様なことが できる、またロボットとパソコンは，RS-232C で接続 し，ロボットの動作データ（SCOL-I で記述された動作 プログラムと位置データ）を伝送したり，ロボットの起

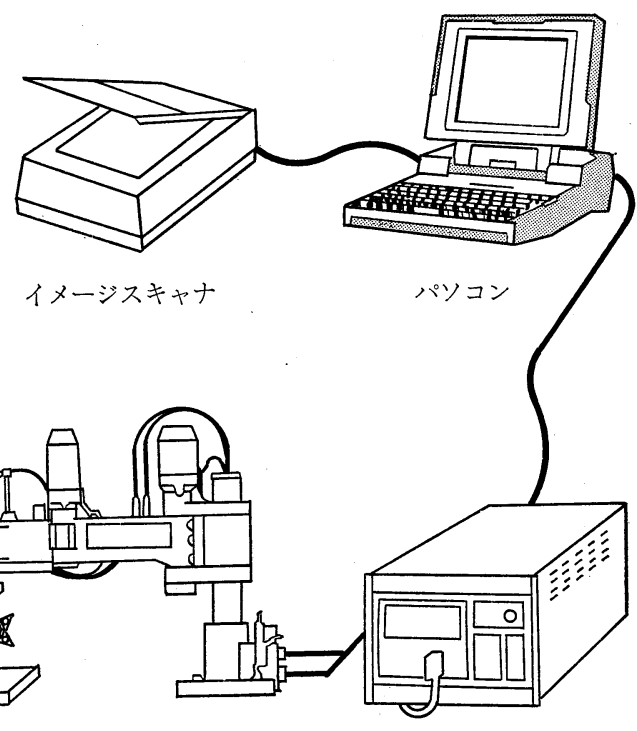

ロボット

ロボット・コントローラ

図 1 システム構成 


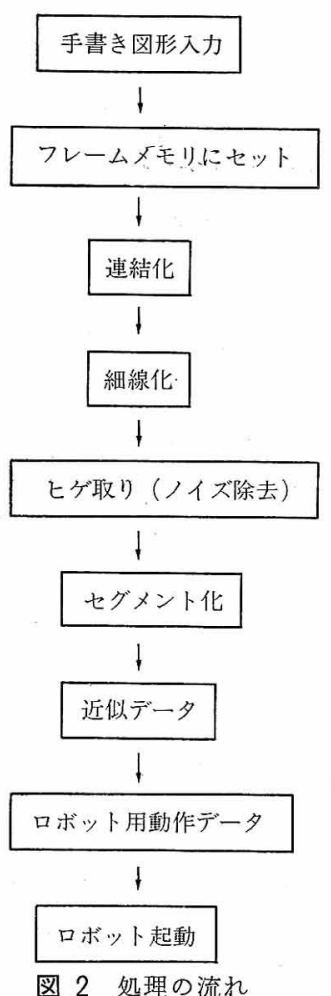

動・停止等を行ならことができる。

\section{3. ソフトウェア構成}

ソフトウェアは，画像処理部，2次元 $\mathrm{CAD}$ 部，オフ ライン・プログラミング部，通信機能部から構成してい る. 全体の処理概要を説明すると, 画像処理部は, イメ ージ・スキャナによって手書き図形を入力し，画像処理 を行ない，直線列の $\mathrm{CAD}$ データに変換する. この変換 されたデータを，2次元 $\mathrm{CAD}$ 部（東芝製 $\mathrm{CAD}$ システ ム CS-3100）を利用して図形の編集（図形，文字等の追 加・修正等）を行ないロボットの軌跡となる図形を作成 し，またこの図形にロボットの作業に必要なデータを付 け加光る、そして，オフライン・プログラミンダ部でこ のデータよりロボットの動作データを生成する，そして, 通信機能部でこの動作データをロボット・コントローラ に伝送し、ロボットを動かす。

以下に，それぞれの機能について，\&5少し詳しく説 明する (図 2 参照). 画像处理部は,イメージ・スキャナ で入力した画像，すなわち点の情報を図形として処理し やすい直線列のデータに変換する．その処理手順は，ま ずイメージ・スキャナで入力図形を白い所は 0 ，黒い 所は1のドット・パターンとしてメモリ上汇読み达む. このデータをフレーム・メモリにマスタ・パターンとし

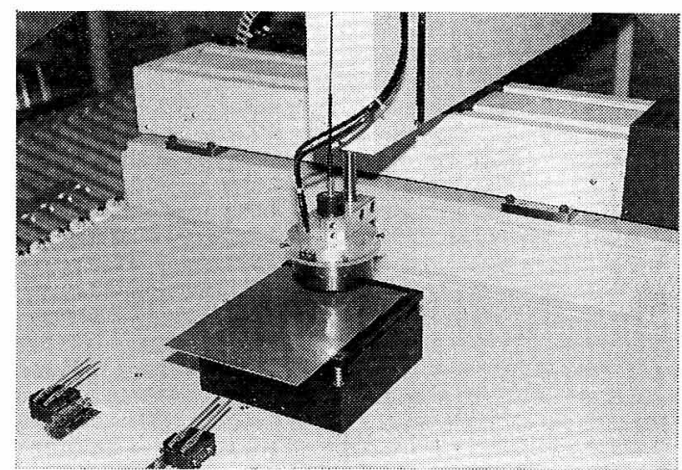

写真 1 マーキングに使用したロボット

てセットする.

次に画像中の図形として欠けている部分（ドット）を 埋めてドット・データの連結化を行う.そして, 数ドッ トの幅をるった画像を，1ドットの幅にする細線化を行 う. 次に，ヒゲのようにとび出した部分のデータを取り 除いて図形を整えるヒゲ取り処理を行う.

こうして整壳られた図形を，分岐点間ごとにセグメン 卜化し，そのセグィント単位で，直線近似を行ない，直 線列の図形とする。この時, 直線近似の精度は，パラメ 一タで指定でき，精度をよくすると入力図形により近い データが得られるが，データ量が多くなる.

この直線列に変換したデータを 2 次元 CAD 入力デー タに変換する. この変換したデータを 2 次元 $\mathrm{CAD}$ へ 力し, 図形の追加や，削除といった図形の編集作業を行 ない，口ボットの軌跡となる図形を作成する，又図形に 対して, ロボットの作業に必要なッール・オフセット， 加工条件（例光ば，シーリング作業の場合シーリングを ON するとか OFF するとかの条件で，実際の ON/ OFF する作業は，ロボット・コントローラにサブルー チンとして作成して数き，サブルーチン CALL するよ ようにロボット動作プログラムを作成する。)，ロボット の Z 軸座標值 (図形が 2 次元のため), 作業対象とする ロボットの種類（使用するロボットによりパラメータが 異なる為), ワーク位置補正 (CAD 上の図形をロボット で作業させたい位置に合わせる機能で，図形を作る時に ロボットの作業位置を考党ずに作成できる.) 等のデー タを付け加える. 次にロボットが動作する順序を指定す る. 指定方法は 2 種類あり，1つは，図形要素を個々に 指定する方法で，もう 1 つは領域を指定する方法である。 領域を指定する方法では, 領域内の図形要素より, ロボ ット動作時間を最短にするように動作順序を決める。

これらのデータを元にロボット用動作データ（ロボッ トの動作を示すプログラムと位置データ）を生成する. 


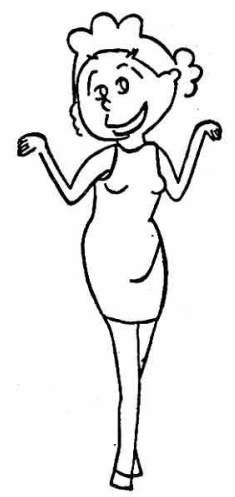

図 3 手書き図形

そして，作成されたロボット用動作データをロボット・ コントローラに伝送し，ロボットを起動して軌跡作業を 行う.

\section{4. 使用例}

このシステムで教示し， ロボットでマーキング作業を 行なった例を紹介する。

マーキングに使用したロボットは，東芝製直角座標形 ロボット SR-641 L 3 ( 3 軸構成で 可動範囲 $600 \mathrm{~mm} \times$ $400 \mathrm{~mm} \times 100 \mathrm{~mm}$ ) で, 写真1に示すようにロボット手 先に YAGレーザ・ノズルを取付け YAG レーザでのマ ーキング等の作業が行なえるようになっている．図３は， イメージ・スキャナに入力した手書き図形で，原稿サイ ズは A 4 版の大きさである.

この手書き図形をイメージ・スキャナに入力し，読み 取り密度 180 ドット/インチで読むと，1520×2104 ドッ トの大ささとしてメモリに入力される. この入力したデ

一タを，そのまま表示したのが写真 2 である.

この入力したデータに画像処理を行ない CAD 用デー タに変換し, $\mathrm{CAD}$ で変換した CAD 用データを表示し

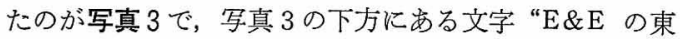
芝”之四角の枠は CAD を利用して入力したものである。 この図形をロボット用動作データに変換して，ロボッ ト・コントローラへ伝送し， ロボットでマーキング作業 を行なった結果を写真 4 に示す.

図形を入力し，ロボットが作業するまで約 15 分であ る.この時の画像処理時間は約 10 分である.

このような図形を CAD に入力することは，CAD た けの機能では手間がかかり，大変な作業であるが，この システムを利用するとイメージ・スキャナに手書き図形 を入力することで，自動的に CAD データに変換でさる. したがってオペレータは，口ボットの動作イメージを， 紙の上に描くだけでロボットのティーチングが簡単に行

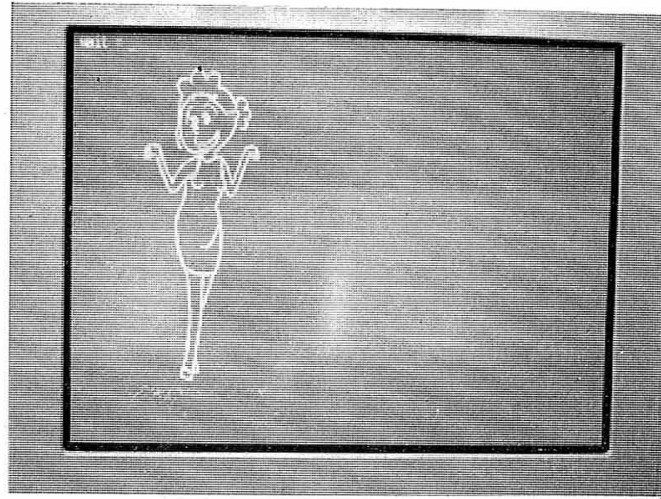

写真 2 イメージ・スキャナで読み込んだ手書き図形

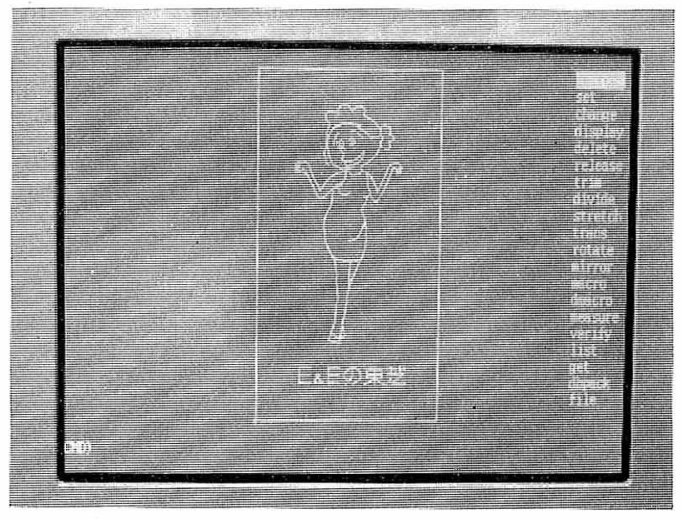

写真 3 手書き図形を画像処理後 CAD で表示

なえる、

また,このシステムは, 例えば $1 \mathrm{~mm}$ の線幅図形に対 し, 画像処理を行なった場合, $\pm 0.5 \mathrm{~mm}$ の精度でデー タ変換を行ならので， あまり高い精度が要求されない多

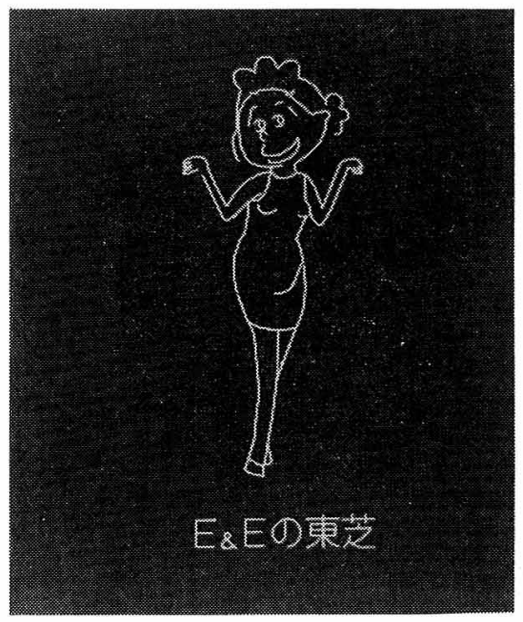

写真 4 口ボットによるマーキング 
品種のワークに対する図形を入力する場合，手書き図形 を入力できるシステムが有効となる.

\section{5. あとがき}

ロボットでマーキング等の軦跡作業を行なら教示方法 の簡易化として，安価なイメージ・スキャナを利用した オフライン・ティーチング・システムを開発した. 今後 は, さらに機能を充実させ, 又実際のアプリケーション に応用し発展させる予定である。

\section{参考文 献}

1）川辺，小川，岩崎：“アーク溶接ロボット用オフライン・ ティーチング・ンステム”日本ロボット学会第 4 回学術 講演会予稿集

2）川村, 田中, 石川：“パソコンを利用したオフライン・ ティーチング・システムの開発”日本ロボット学会第 4 回学術講演会予稿集

3）若原：“オフライン・ロボット・プログラミング・シス テム”日本ロボット学会第 4 回学術講演会予稿集

4) 田中, 川村, 青木, 熊谷, 藤田: Robot Planner・ロボ ット行業計画開発支援システム”日本ロボット学会第 4 回学術講演会予稿集
5）毎川，天野：“2 次元 $\mathrm{CAD}$ を利用したオフライン・テ イーチング・システム 第 1 報”日本ロボット学会第 6 回学術講演会予稿集

6）天野，每川：“2 次元 CAD を利用したオフライン・テ イーチング・システム 第2 報 イメージ・スキャナに よる図形入力”日本ロボット学会第 6 回学術講演会予稿 集

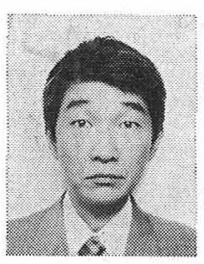

\section{毎川保久}

(Yasuhisa MAIKAWA)

昭和 49 年早稲田大学理工学部卒業, 同 年 (株) 東芝入社, 重電技術研究所勤務.

（日本ロボット学会正会員）

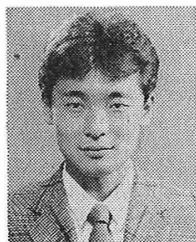

\section{天野光明}

(Mitsuaki AMANŌ)

昭和 58 年香川県立多度津工業高等学校 電子科卒，同年（株）東芝入社，重電技術 研究所勤務.

(日本ロボット学会正会員) 